\title{
Impact of Growth Biostimulators and Herbicide on the Content of Major Protein in Edible Potato Tubers
}

\author{
Alicja Baranowska ${ }^{1 *}$, Iwona Mystkowska' , Krystyna Zarzecka², Elżbieta Szczygielska³ \\ 1 Department of Agriculture, Pope John II State School of Higher Education in Biala Podlaska, Sidorska 95/98, \\ 21-500 Biała Podlaska, Poland \\ 2 Department of Agrotechnology, University of Natural Sciences and Humanities in Siedlce, Prusa 14, 08-110 \\ Siedlce, Poland \\ 3 Department of Construction, Pope John II State School of Higher Education in Biala Podlaska, Sidorska 95/98, \\ 21-500 Biała Podlaska, Poland \\ * Corresponding author's e-mail: alabar@tlen.pl
}

\begin{abstract}
New solutions which would allow for the realization of two basic objectives, i.e. production-related and environmental ones, continue to be sought in plant production. Hence, the purpose of research was to define the impact of five methods of potato field treatment with the application of growth biostimulators and herbicide on the content and harvest of major protein Solanum tuberosum L. Field experiments were carried out in the years 2015-2016 in the region of Eastern Poland $\left(52^{\circ} 02^{\prime} \mathrm{N} ; 2^{\circ} 07^{\prime} \mathrm{E}\right)$. The experiment was performed in the split-plot system in three replications. The tested factors included: I. Factor - two early edible potato cultivars (Owacja, Bellarosa), II. Factor - methods of treatment with the application of growth biostimulators: GreenOk-Uniwersal Pro and Asahi SL and their combination with Avatar 293 ZC herbicide. As a result of the carried out research, it was noted that the methods of treatment applied in the experiment had a beneficial effect on the value of tested features in comparison to the control object, treated exclusively mechanically (without the use of biostimulators and herbicide). Both in terms of protein concentration and the obtained crop of major protein, the application of mechanical treatment for sprouting of potato plants and Avatar $293 \mathrm{ZC}$ herbicide at a dose of $1.5 \mathrm{dm}^{3} \cdot \mathrm{ha}^{-1}$ directly before the sprouting and subsequently post sprouting, triple application of GreenOK Universal-PRO bioactivator at the following doses: $0.10 \mathrm{dm}^{3} \cdot \mathrm{ha}^{-1}+0.15 \mathrm{dm}^{3} \cdot \mathrm{ha}^{-1}+0.15$ $\mathrm{dm}^{3} \cdot \mathrm{ha}^{-1}$ was the most beneficial. The average content of major proteins in this object amounted to $8.14 \%$ while the average protein yield $-750.09 \mathrm{~kg} \cdot \mathrm{ha}^{-1}$.
\end{abstract}

Keywords: Solanum tuberosum L., major protein, biostimulators, herbicide

\section{INTRODUCTION}

In accordance with the Resolution of the United Nations Organization, protection of biological diversity, balanced use of ecosystems is one of the core purposes of agriculture and development of rural areas. Within the plant production, ecological aspect is of great significance; its objective being the proper use of resources of environment and maintenance, or restoring longterm natural balance [Scherr and McNeely, 2008; Hołownicki et al., 2011; Jarecki and BobreckaJamro, 2013; Resolution of United Nations Or- ganization, 2015]. Searching for compromises between the ecological and economic criteria has been supported by the concept of sustainable growth, developed since the 1970s. Within its framework, a permanent and fair growth stands for, among others, observing ecology and economy rights in the decision-making processes [Kozłowski, 2007; Piwowar, 2011].

At present, within the plant production, modern solutions are pursued, targeted at ensuring that the plants obtain the most beneficial conditions for growth [Filipczak et al., 2016]. Application of mineral fertilizers and chemical agents for plant 
protection and the protection of natural environment as well as reaching the high quality of crops with pro-health qualities are the key goals faced by food producers [Koziara et al., 2006; Filipczak et al., 2016; Pszczółkowski and Sawicka, 2018].

In agricultural practice, the application of various types of agri-ecosystem friendly preparations specified as biostimulators has become more and more common [Van Oosten, 2017]. They limit the usage of agri-chemicals and thus, they contribute to the growth of balanced methods of plant production (Radkowski and Radkowska, 2014; Calvo et al., 2015; Du Jardin, 2017).

Biostimulators are defined as the preparations which stimulate the life processes of plants, increasing their resistance to stress conditions [Matysiak and Adamczewski, 2009; Golian et al., 2014; Matyjaszczyk, 2015]. These preparations may be synthetic or natural. Their chemical composition consists of bioactive compounds, among others: nitrophenols, chemical elements, humus substances, useful microorganisms, vitamins, amino acids, citokinins, auxins and other substances included in the category of plant hormones [Hamza and Suggars, 2001; Bulgari et al., 2015]. The use of biostimulators is particularly recommended under unbeneficial plant growth and development conditions [Matysiak and Adamczewski, 2009].

These preparations find an increasingly wider use in agricultural practice, also including potato cultivation, which has become an important plant from the nutritional point of view. In particular, bearing in mind the fact that it is consumed on a daily basis by over a billion of people worldwide [Bishwoyog et Swarnima, 2016; Baranowska, 2018].

The nutritional value of potato is impacted greatly by the content and biological quality of substances of which it is composed [Haase, 2007]. Edible potato tuber consists on average of $77 \%$ of water, $16 \%$ of starch, $0.5 \%$ of sugar, more than $1 \%$ of minerals, $2.3 \%$ of fibre, $0.1 \%$ of lipids and approx. $2 \%$ of protein [Leszczyński, 2012]. The potato protein is characterized by a large biological value, comparable to the soya protein and its value is almost as high as the value of eggwhite which is considered a reference protein. It is rich in essential amino acid that is the substances an organism is unable to synthesize on its own (leucine, lysine, isoleucine, phenylalanine and threonine) [Mazurczyk et al., 2008; Achmed et al., 2010].
There is approx. $1.7-2.9 \%$ of total protein within an average fresh potato tuber (35-60\% of which is major protein). In comparison to, for instance, beans (average content of protein $-21 \%$ ) this amount is rather insignificant; however, taking into consideration the fact that potato is a plant which occurs on a daily basis within our diet (the consumption in Poland amounts to approx. $100 \mathrm{~kg} /$ person/year) and the fact that it is cultivated in around 160 countries worldwide, it is deemed as the plant which plays a crucial role in human nutrition [Zarzecka and Gugała, 2006; Leszczyński, 2012; Pszczółkowski and Sawicka, 2016; Zimnoch-Guzowska and Flis, 2006]

Despite an increasing involvement of science and agricultural practice within the use of growth biostimulators, the possibility of applying these preparations in agricultural practice is not yet fully recognized. Therefore, the aim of the experiment was to define the influence of five treatment methods with the use of growth biostimulators and herbicide on the content and crop of total protein of the three tested edible potato cultivars. The research hypothesis assumed that the methods of treatment with the application of biostimulators and herbicide will beneficially affect the content and crop of total protein.

\section{MATERIALS AND METHODS}

\section{Experiment and plant material}

The field research was conducted in years 2015-2016 in the area of eastern Poland in Biała Podlaska commune $\left(52^{\circ} 02^{\prime} \mathrm{N}\right.$; $\left.23^{\circ} 07^{\prime} \mathrm{E}\right)$, in Lublin Voivodship, on light, acidic soil. The impact of two factors was analysed:

- Factor 1 - potato cultivars: Bellarosa, Owacja;

- Factor 2 - methods of application of biostimulators and herbicide:

1) Standard object - mechanical treatment (without biostimulators and herbicide).

2) From sprouting of potato plants - mechanical treatment and after sprouting - GreenOK Universal-PRO bioactivator, three times to leaves: at a dose of $0.10 \mathrm{dm}^{3} \cdot \mathrm{ha}^{-1}$ - peak-end of sprouting $+0.15 \mathrm{dm}^{3} \cdot \mathrm{ha}^{-1}-$ covering of interrows + $0.15 \mathrm{dm}^{3} \cdot \mathrm{ha}^{-1}$ - flower bud break;

3) From sprouting of potato plants - mechanical treatment, and after sprouting - Asahi SL 


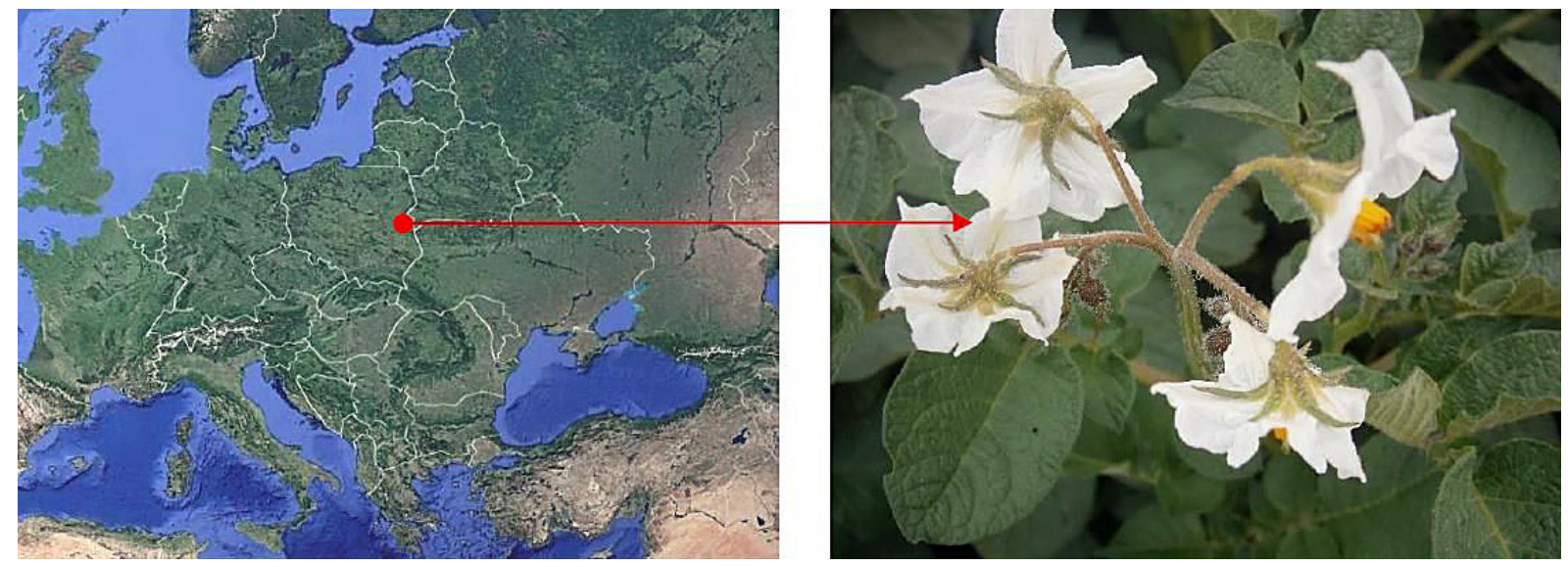

Figure 1. Experiment location

bioactivator, three times to leaves at a dose of $0.50 \mathrm{dm}^{3} \cdot \mathrm{ha}^{-1}$ - peak-end of sprouting +0.50 $\mathrm{dm}^{3} \cdot \mathrm{ha}^{-1}-$ covering of interrows $+0.50 \mathrm{dm}^{3}$ $\cdot \mathrm{ha}^{-1}$ - flower bud break.

4) From sprouting - mechanical treatment, and after the final shaping of ridges and just before sprouting Avatar 293 ZC herbicide at a dose of $1.5 \mathrm{dm}^{3} \cdot \mathrm{ha}^{-1}$. After sprouting - three applications of GreenOK Universal-PRO bioactivator at a dose of $0.10 \mathrm{dm}^{3} \cdot \mathrm{ha}^{-1}-$ peak-end of sprouting +0.15 $\mathrm{dm}^{3} \cdot \mathrm{ha}^{-1}-$ covering of interrows $+0.15 \mathrm{dm}^{3} \cdot \mathrm{ha}^{-1}$ - flower bud break.

5) From sprouting - mechanical treatment, and after the final shaping of ridges before sprouting of potato plants - Avatar 293 ZC herbicide at a dose of $1.5 \mathrm{dm}^{3} \cdot \mathrm{ha}^{-1}$.

In accordance with the producer's information (Latvian Institute of Humus Substances) the GreenOK Universal-PRO preparation is a bioactive organic fertilizer of natural origin. It is made of high quality peat consisting of the concentrate of humus substances $(\leq 20$ $\left.\mathrm{g} \mathrm{dm}^{3}\right)$ and NPK elements (0.13-0.09-0.7\%). Its biological activity consists in, among others: increasing the bioavailability of nutrients, stimulating of growth of the weakened part of plants, prolonging the flowering time and increasing the number of flowers, reducing the negative impact of unbeneficial environmental factors. Asahi SL preparation contains three active substances from the group of nitrophenols: sodium para-nitrophenol $-0.3 \%$, sodium ortho-nitrophenol $-0.2 \%$ and sodium 5 -nitroguaiacol $-0.1 \%$. These compounds occur naturally in plant cells and participate in physiological and biochemical processes of plants [Babuška, 2004]. The Avatar 293 ZC herbicide applied in the experiment contains two active substances with a complementing mechanism of action involving clomazone, inhibiting the synthesis of pigments in plants (chlorophyll and carotenoids) and metribuzin, inhibiting the process of photosynthesis (Label on plant protection agent Avatar 293 ZC).

Each year, natural manure fertilization was used at a dose of $25 \mathrm{t} \cdot \mathrm{ha}^{-1}$, as well as mineral fertilization with phosphorus $44.0 \mathrm{~kg} \mathrm{P} \cdot \mathrm{ha}^{-1}$ (triple superphosphate $46 \%$ ) and potassium $124.5 \mathrm{~kg} \mathrm{~K} \cdot \mathrm{ha}^{-1}$ (potassium salt $60 \%$ ), and nitrogen fertilization (ammonium nitrate 34\%) at a dose of $100 \mathrm{~kg} \mathrm{~N}$ per 1 ha. Protection treatments against diseases and pests were performed in accordance with the plant protection recommendations.

\section{Chemical analyses}

The chemical analyses were carried out on dry material in three repetitions. General nitrogen was marked by means of Kjeldahl's method on Kjeltec 8400 unit [Ostrowska et al. 1991]. The content of total protein was calculated from the content of general nitrogen applying the coefficient $6.25(\% \mathrm{~N}$ general x $6.25=$ total protein ( $\%$ in dry mass). Total protein crop was calculated as product of dry mass crop of tubers and the content of total protein.

\section{Statistical analysis}

Statistical calculations were conducted by means of STATISTICA, v 10 software package (StatSoft, Inc., 2011) with the use of the one-way 
analysis of variance (ANOVA) and Student's t-test for independent groups. In the case of the detected correlations, multiple comparison tests were applied (NIR). The level of significance of 0.05 was assumed.

\section{Weather conditions}

In the course of research, the weather conditions were rather diverse (see Figure 2-3).
The growing season of 2016 was far more humid than the growing season of 2015. The following months were particularly humid: July with total precipitation of $121 \mathrm{~mm}$ and high air temperatures (on average $19.8^{\circ} \mathrm{C}$ ) and June with total precipitation of $84 \mathrm{~mm}$ and an average air temperature of $18.4^{\circ} \mathrm{C}$. Within the growing season of 2015, the shortage of precipitation occurred in June and July and, in particular, August was a dry month.

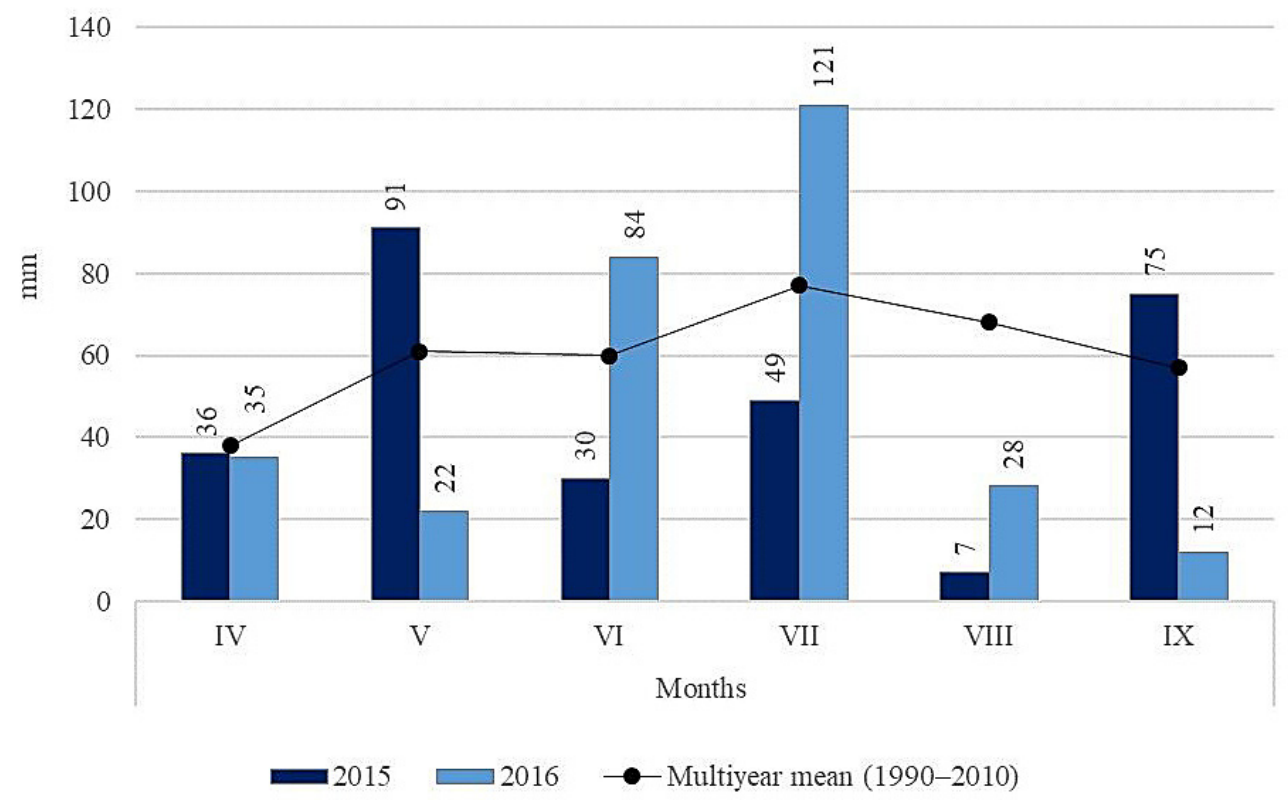

Figure 2. Rainfall in the vegetation period of potato in 2015-2016 (mm)

[Source: Central Research Centre of Agricultural Plant Cultivars in Słupia Wielka - elaboration for the commune of Biała Podlaska]

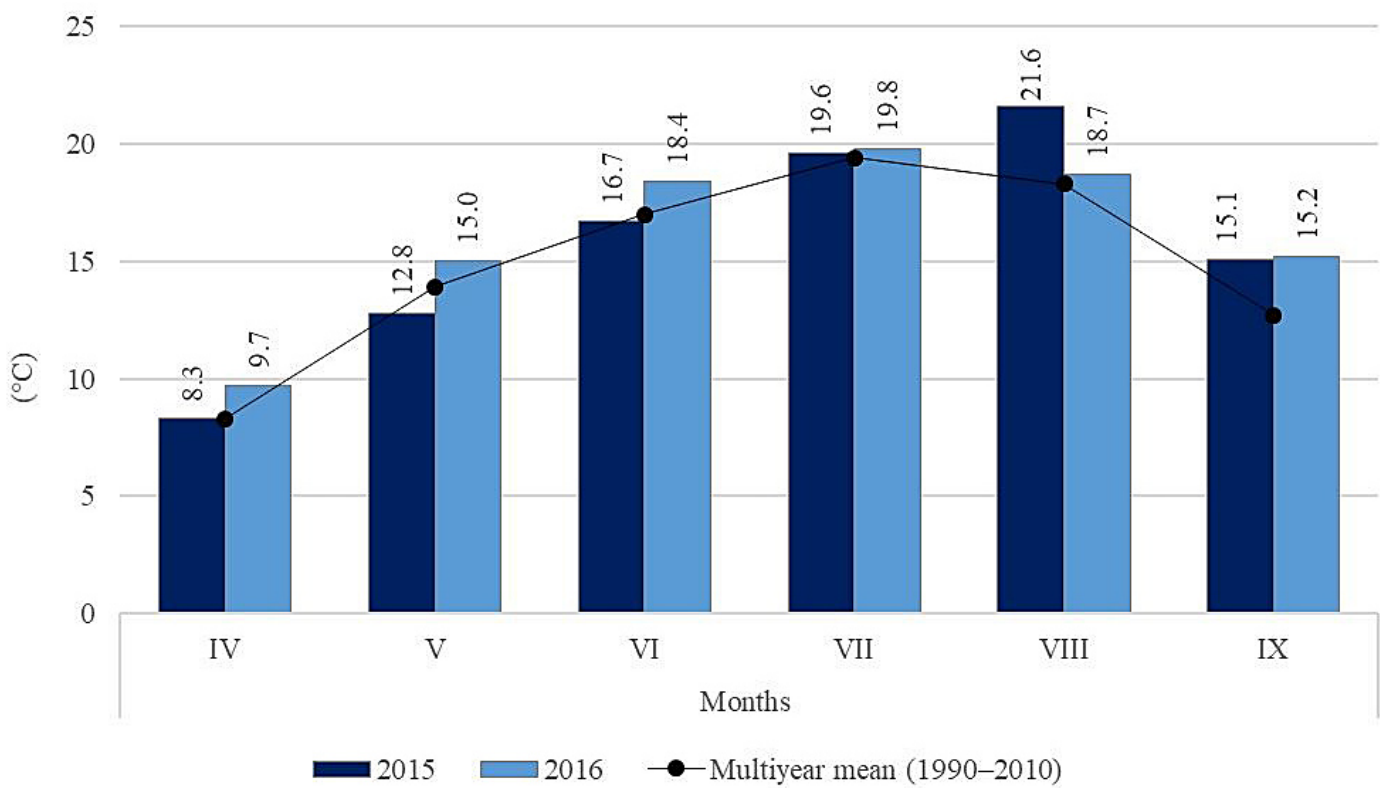

Figure 3. Air temperature during the growing season of potato in $2015-2016\left({ }^{\circ} \mathrm{C}\right)$

[Source: Central Research Centre of Agricultural Plant Cultivars in Słupia Wielka - elaboration for the commune of Biała Podlaska] 


\section{RESULTS AND DISCUSSION}

As a result of the carried out research it was noted that the application within the experiment of the treatment method involving the use of growth biostimulators and herbicide had a beneficial impact on the content of total protein in potato tubers (object 2-5) in comparison to the treatment applying solely the mechanical method (object 1). Statistically significant differences occurred in the case of object 1 and 4 (a) and in the case of object 3 and 4 (b) (Table 1). The largest concentration of protein (on average $8.14 \%$ ) was noted in the tubers gathered from object 4 (in the case of which mechanical treatment was applied for sprouting, followed by applying Avatar $293 \mathrm{ZC}$ herbicide at a dose of $1.5 \mathrm{dm}^{3} \cdot \mathrm{ha}^{-1}$, and after sprouting, triple application of GreenOK Universal-PRO bioactivator at a dose of $0.10 \mathrm{dm}^{3} \cdot \mathrm{ha}^{-1}+0.15 \mathrm{dm}^{3} \cdot \mathrm{ha}^{-1}+$ $0.15 \mathrm{dm}^{3} \cdot \mathrm{ha}^{-1}$. The beneficial impact of growth biostimulators on qualitative features of potato tubers was also reported by Mikos-Bielak [2005], Zarzecka and Gugała [2012], Wierzbowska et al. [2015], Sawicka et al. [2016]. According to Wichrowska et al. [2009], Rymu- za et al. [2013]; also the method of treatment involving the use of herbicides has a positive impact on the increase of total protein content in potato tubers.

Greater stability in cumulation of total protein was reported in the case of Owacja cultivar, than Bellarosa cultivar (Table 2), having gathered on average $7.65 \%$ of protein in 2015 and $7.75 \%$ of protein in 2016, respectively. These values are similar to the values obtained by Jansen et al. [2001] and Jansen and Flamme [2006], who, upon testing of 460 or more cultivars of potatoes, obtained the total protein content in dry mass of tubers at the level between 4.50 and $13.60 \%$ and between 4.38 and 12. $46 \%$. In 2016 , significantly higher concentration of total protein was noted in the potato tubers of Owacja cultivar when compared to the Bellarosa cultivar. According to Bártová et al. [2009] the cultivars of potato differ with genetically conditioned predisposition for the cumulation of protein. The cultivar nature of diversity of the protein content in various tubers may be determined by: changes in chemical composition of individual parts of potato plants, distribution of nitrogen and diverse ni-

Table 1. The content of total protein [\%] in potato tubers, depending on the treatment methods (average level for the years 2015-2016)

\begin{tabular}{|c|c|c|c|}
\hline Methods of treatment & Average protein content [\%] & Number of objects & Standard deviation \\
\hline $1^{* *}$ & ${ }^{*} 6.74^{(\mathrm{a})}$ & 12 & 1.26 \\
\hline 2 & 7.57 & 12 & 1.16 \\
\hline 3 & $7.02^{(\mathrm{b})}$ & 12 & 0.65 \\
\hline 4 & $8.14^{(\mathrm{a}, \mathrm{b})}$ & 12 & 1.13 \\
\hline 5 & 7.41 & 12 & 1.26 \\
\hline Total & 7.38 & 60 & 1.18 \\
\hline
\end{tabular}

$F=2.80 ; p=0.0347$.

$*$ (a); (b) - statistically significant differences at $\mathrm{p}<0.05$.

** - as per research methodology: 1. Standard object (without biostimulators and herbicide); 2 . GreenOK Universal-PRO $0.10 \mathrm{dm}^{3} \cdot \mathrm{ha}^{-1}+0.15 \mathrm{dm}^{3} \cdot \mathrm{ha}^{-1}+0.15 \mathrm{dm}^{3} \cdot \mathrm{ha}^{-1} ; 3$. Asahi SL $0.50 \mathrm{dm}^{3} \cdot \mathrm{ha}^{-1}+0.50 \mathrm{dm}^{3} \cdot \mathrm{ha}^{-1}+0.50 \mathrm{dm}^{3} \cdot \mathrm{ha}^{-1}$; 4. Avatar $293 \mathrm{ZC} 1.5 \mathrm{dm}^{3} \cdot \mathrm{ha}^{-1}+$ GreenOK Universal-PRO $0.10 \mathrm{dm}^{3} \cdot \mathrm{ha}^{-1}+0.15 \mathrm{dm}^{3} \cdot \mathrm{ha}^{-1}+0.15 \mathrm{dm}^{3} \cdot \mathrm{ha}^{-1} ; 5$. Avatar $293 \mathrm{ZC} 1.5 \mathrm{dm}^{3} \cdot \mathrm{ha}^{-1}$.

Table 2. Average content of total protein [\%] in potato tubers depending on the cultivars and years of research

\begin{tabular}{|c|c|c|c|c|c|c|c|c|}
\hline \multirow[b]{2}{*}{ Variety } & \multicolumn{3}{|c|}{ Year $2015(t=-0.58 ; p=0.5637)$} & \multicolumn{3}{|c|}{ Year $2016(t=-3.64 ; p=0.0011)$} & \multirow[b]{2}{*}{$t$} & \multirow[b]{2}{*}{$p$} \\
\hline & $\begin{array}{c}\text { Average protein } \\
\text { content [\%] }\end{array}$ & $\begin{array}{c}\text { Number of } \\
\text { objects }\end{array}$ & $\begin{array}{l}\text { Standard } \\
\text { deviation }\end{array}$ & $\begin{array}{c}\text { Average protein } \\
\text { content [\%] }\end{array}$ & $\begin{array}{l}\text { Number of } \\
\text { objects }\end{array}$ & $\begin{array}{l}\text { Standard } \\
\text { deviation }\end{array}$ & & \\
\hline Bellarosa & 7.35 & 15 & 1.55 & ${ }^{*} 6.75^{(\mathrm{a})}$ & 15 & 0.76 & 1.33 & 0.1939 \\
\hline Owacja & 7.65 & 15 & 1.29 & $7.75^{(\mathrm{a})}$ & 15 & 0.74 & -0.25 & 0.8038 \\
\hline Total & 7.50 & 30 & 1.41 & 7.25 & 30 & 0.89 & 0.82 & 0.4175 \\
\hline
\end{tabular}

*(a) - statistically significant differences at $\mathrm{p}<0.05$. 
trogen metabolism [Lis et al., 2002; Zebarth et al., 2004]. Mustonen [2004] also noted that the state of growth of plants in the course of their harvesting may have a significant impact on the content of protein in their tubers.

Within his own research, a slightly higher content of total protein was noted in the tubers gathered in dry and warm growing season of 2015 (on average $7.50 \%$ ) than within the growing season of 2016 (on average $-7.25 \%$ ), when greater precipitation was reported (Table 2). According to Wierzbicka and Trawczyński [2011] as well as Trawczyński [2016], warm, dry and sunny growing period has a stimulating impact on the content of total protein; whilst, excessive rainfall in the period of harvesting may lead to washing out of nitrogen from the soil which is related to the limited intake of this component by tubers.

The size of total protein crop in potato tubers is governed mainly by the crops of dry mass in the tubers as well as the content of total protein within them, which may be modified by individual experiment factors to a significant degree.
It was noted that the treatment methods applied in the experiment positively affected the total protein crop of potato tubers (object 2-4) in comparison to the control object (object 1). The greatest protein crop was reported following the application of Avatar 293 ZC herbicide jointly with GreenOK Universal-PRO biostimulator (on average $750.09 \mathrm{~kg} \cdot \mathrm{ha}^{-1}$ ), (object 4) (Table 3).

The genetic features of potato cultivars had a significant impact on the size of the yield of total protein crop of starch of tubers. Higher crop of protein was obtained in the case of Owacja cultivar when compared to Ballarosa cultivar (Table 4). Potato is a species which clearly reacts to the weather conditions during the growing period [Puła and Skowera, 2004]. Within own research, higher crop of total protein was obtained in 2016 (on average 620.52 $\mathrm{kg} \cdot \mathrm{ha}^{-1}$ ), than in 2015 (on average 585.77 $\mathrm{kg} \cdot \mathrm{ha}^{-1}$ ); however, these differences were not confirmed statistically. Similar results were obtained by Bombik et al. [2007], Gugała et al. [2008] as well as Wierzbicka and Trawczyński, 2012], who noted that the potato crop, as well as the content of nutrients in tubers depend on the weather conditions.

Table 3. Crop of total protein depending on the treatment method (average level for the years 2015-2016 [kg $\left.\cdot \mathrm{ha}^{-1}\right]$

\begin{tabular}{|c|c|c|c|}
\hline Method of treatment & Average total protein crop $\left[\mathrm{kg} \cdot \mathrm{ha}^{-1}\right]$ & Number of objects & Standard deviation \\
\hline $1^{*}$ & ${ }^{* *} 434.52^{(\mathrm{a}, \mathrm{b}, \mathrm{c}, \mathrm{d})}$ & 12 & 108.58 \\
\hline 2 & $599.88^{(\mathrm{a}, \mathrm{e})}$ & 12 & 140.05 \\
\hline 3 & $583.88^{(\mathrm{b}, \mathrm{f})}$ & 12 & 108.15 \\
\hline 4 & $750.09^{(\mathrm{c}, \mathrm{e}, \mathrm{f})}$ & 12 & 158.96 \\
\hline 5 & $647.33^{(\mathrm{d})}$ & 12 & 127.52 \\
\hline Total & 603.14 & 60 & 162.57 \\
\hline
\end{tabular}

$F=9.28 ; p<0.0001$.

* (a, b, c, d, e, f) - statistically significant differences at $\mathrm{p}<0.05$.

** - as per research methodology: 1. Standard object (without biostimulators and herbicide); 2 . GreenOK Universal-PRO $0.10 \mathrm{dm}^{3} \cdot \mathrm{ha}^{-1}+0.15 \mathrm{dm}^{3} \cdot \mathrm{ha}^{-1}+0.15 \mathrm{dm}^{3} \cdot \mathrm{ha}^{-1} ; 3$. Asahi SL $0.50 \mathrm{dm}^{3} \cdot \mathrm{ha}^{-1}+0.50 \mathrm{dm}^{3} \cdot \mathrm{ha}^{-1}+0.50 \mathrm{dm}^{3} \cdot \mathrm{ha}^{-1}$; 4. Avatar $293 \mathrm{ZC} 1.5 \mathrm{dm}^{3} \cdot \mathrm{ha}^{-1}+$ GreenOK Universal-PRO $0.10 \mathrm{dm}^{3} \cdot \mathrm{ha}^{-1}+0.15 \mathrm{dm}^{3} \cdot \mathrm{ha}^{-1}+0.15 \mathrm{dm}^{3} \cdot \mathrm{ha}^{-1} ; 5$. Avatar $293 \mathrm{ZC} 1.5 \mathrm{dm}^{3} \cdot \mathrm{ha}^{-1}$.

Table 4. Crop of total protein in potato tubers $\left[\mathrm{kg} \cdot \mathrm{ha}^{-1}\right]$ depending on the cultivars and years of experiments (2015-2016)

\begin{tabular}{|c|c|c|c|c|c|c|c|c|}
\hline \multirow[b]{2}{*}{ Variety } & \multicolumn{3}{|c|}{ Year $2015(t=-2.08 ; p=0.0467)$} & \multicolumn{3}{|c|}{ Year $2016(t=-5.82 ; p<0.0001)$} & \multirow[b]{2}{*}{$t$} & \multirow[b]{2}{*}{$p$} \\
\hline & $\begin{array}{c}\text { Average total } \\
\text { protein crop } \\
{\left[\mathrm{kg} \cdot \mathrm{ha}^{-1}\right]}\end{array}$ & $\begin{array}{c}\text { Number of } \\
\text { objects }\end{array}$ & $\begin{array}{l}\text { Standard } \\
\text { deviation }\end{array}$ & $\begin{array}{l}\text { Average total } \\
\text { protein crop } \\
{\left[\mathrm{kg} \cdot \mathrm{ha}^{-1}\right]}\end{array}$ & $\begin{array}{c}\text { Number of } \\
\text { objects }\end{array}$ & $\begin{array}{l}\text { Standard } \\
\text { deviation }\end{array}$ & & \\
\hline Bellarosa & ${ }^{*} 528.46^{(a)}$ & 15 & 150.85 & *499.25(b) & 15 & 90.58 & 0.64 & 0.5254 \\
\hline Owacja & $643.07^{(\mathrm{a})}$ & 15 & 150.73 & $741.78^{(b)}$ & 15 & 133.62 & -1.90 & 0.0680 \\
\hline Total & 585.77 & 30 & 159.22 & 620.52 & 30 & 166.71 & 0.83 & 0.4124 \\
\hline
\end{tabular}

* (a); (b) - statistically significant differences at $\mathrm{p}<0.05$. 


\section{CONCLUSIONS}

The current use of growth biostimulators in plant production attracts great interest both among the producers themselves and the scientists. GreenOk-Universal Pro and Asahi SL biostimulators applied in the experiment, and their combination with Avatar 293 ZC herbicide had a positive effect on an increase of major protein content as well as on the yield of protein in comparison to the control object treated exclusively mechanically and thus, they increased the nutrition value of potato tubers. Applying growth biostimulators on agricultural plant plantations constitutes a response to the increasing consumer needs as to the quality of foodstuffs of plant origin. It also signifies care and concern about the quality of natural environment; therefore, the growth biostimulators ought to find a wider use in the agricultural practice.

\section{REFERENCES}

1. Ahmed E, Elfaki, Afaf. M. Abbsher. 2010. Nutritional situation of potato subjected to Sudanese cooking methods. J. Appl. Sci. Res., 6 (8), 980-924.

2. Babuška P. 2004. Asahi compendium. ASAHI Chemical, Japan.

3. Baranowska A. 2018. Potato production - analysis on the plantation level Roczniki Naukowe Stowarzyszenia Ekonomistów Rolnictwa i Agrobiznesu, 20 (2), 16-21.

4. Baranowska A., Zarzecka K., Gugała M., Mystkowska I. 2017. Cntents of zinc, copper and manganese in potato tubers depending on the ways of application of the soil fertilizer $\mathrm{UG}_{\max }$. Journal of Ecological Engineering, 18 (1), 99-106.

5. Bártová V., Bárta J., Diviš J., Švajner J., Peterka J. 2009. Crude protein content in tubers of starch processing potato cultivars in dependence on different agro-ecological conditions. J. Central Europ. Agric., 10 (1), 57-65.

6. Bishwoyog B., Swarnima, K.C. 2016. Effect of potassium on quality and yield of potato tubers - a review. International Journal of Agriculture \& Environmental Science, 3,: 9-14.

7. Bombik A., Rymuza K., Markowska M., Stankiewicz C. 2007. Variability analysis of selected quantitative characteristics in edible potato varieties. Acta Sci. Pol., Agricultura, 6 (3), 5-15.

8. Bulgari R., Cocetta, G., Trivellini A., Vernieri P., Ferrante A. 2015. Biostimulants and crop responses: a review. Biological Agriculture \& Horticulture, $31(1), 1-17$.
9. Calvo P., Nelson L., Kloepper J.W. 2014. Agricultural uses of plant biostimulants. Plant Soil, 383, $3-41$.

10. Du Jardin P. 2012. The Science of Plant Biostimulants - A bibliographic analysis. Ad hoc Study Report to the European Commission DG ENTR.

11. Filipczak J., Żurawicz E., Sas Paszt L. 2016. Impact of selected biostimulators on growth and yielding of "Elkat" strawberry [in Polish]. Zeszyty Naukowe Instytutu Ogrodnictwa, 24, 43-58.

12. Golian J., Anyszka Z., Kohut M. 2014. The assessment of herbicides application with biostimulants and adjuvants in carrot (Daucus carota L.). Progress in Plant Protection/Postępy w Ochronie Roślin, 54 (2), 167-173.

13. Gugała M., Zarzecka K., Baranowska A. 2008. Impact of land management and methods of weeding on yields of nutrients and the economic efficiency of potato cultivation. Part I. Crops of nutrients in potato [in Polish]. Acta Sci. Pol., Agricultura, 7 (2), 21-31.

14. Haase N.U. 2007. The canon of potato science: The nutritional value of potatoes. Potato Research, 50, 415-417.

15. Hamza B., Suggars A. 2001. Biostimulants: myths and realities. Turfgrass Trends, 10, 6-10.

16. Hołownicki R., Doruchowski G., Godoń A. 2011. Technology of plant protection within EU Directives [in Polish]. Inżynieria Rolnicza, 4 (129), 75-84.

17. Jansen G., Flamme W. 2006. Coloured potatoes (Solanum tuberosum L.) - anthocyanin content and tuber quality. Genetic Resources and Crop Evolution, 53, 1321-1331.

18. Jansen G., Flamme W., Shüler K., Vandrey M. 2001. Tuber and starch quality of wild and cultivated potato species and cultivars. Potato Research, 44, 137-146.

19. Jarecki W., Bobrecka-Jamro D. 2013. Use of resources for agricultural production in Poland in the context of retardation of agricultural transformations in production space [in Polish]. Inżynieria Ekologiczna, 34, 121-128.

20. Kołodziejczyk M. 2015. Effect of nitrogen fertilization and microbial preparations on N-min content in soil after potato harvesting. Journal of Agricultural Science and Technology, 17 (5), 1245-1254.

21. Koziara W., Sulewska H., Panasiewicz K. 2006. Effect of resistance stimulator application to some agricultural crops. J. Res. Appl. Agric. Eng., 51 (2), 82-87.

22. Kozłowski S. 2007. The future of eco-development [in Polish]. KUL, Lublin.

23. Leszczyński W. 2012. Nutrition value of potato and potato products - Literature overview [in Polish]. Biuletyn Instytutu Hodowli i Aklimatyzacji Roślin, 216, 5-20. 
24. Lis B, Mazurczyk W, Trawczyński C, Wierzbicka A. 2002. Factors inhibiting the use of nitrogen by potato plants versus environmental threat [in Polish]. Zeszyty Problemowe Postępów Nauk Rolniczych, 489, 165-174.

25. Matyjaszczyk E. 2015. Introduction of Biostimulators for Trade in Poland. The Current Situation and Legal Considerations [in Polish]. Przemysł Chemiczny, 94 (10), 1841-1844.

26. Matysiak K., Adamczewski K. 2009. Plant growth regulators application - studies in Poland and in the world. Progress in Plant Protection/Postępy w Ochronie Roślin, 49 (4), 1810-1816.

27. Mazurczyk W., Wroniak J., Wierzbicka A. 2008. Impact of drop irrigation on accumulation of protein crop and try matter in potato tubers [in Polish]. Zeszyty Problemowe Postępów Nauk Rolniczych, 530, 177-186.

28. Mikos-Bielak, M. 2005. Exogenous growth regulators in potato cultivation. Annales UMCS, Sec. E. 60, 281-292

29. Mustonen L. 2004. Yield formation and quality characteristics of early potatoes during a short growing period. Agric Food Sci., 13, 390-398.

30. Ostrowska A., Gawliński S., Szczubiałka Z. 1991. Methods of Analysis and Assessment of Soil and Plant Properties. Edit [in Polish]. Institute of Environment Protection. Warszawa.

31. Piwowar A. 2011. Selected economic and ecological aspects of applying mineral fertilizers in agricultural farming [in Polish]. Ekonomia, 5 (17), 217-230.

32. Pszczółkowski P., Sawicka B. 2016. Nutritional value of the selected potato cultivars [in Polish]. [In]: G. Lewandowicz, J. Le Thanh-Blicharz (Eds.) Bio products - obtained properties and application in foodstuff production. Wydział Nauk o Żywności i Żywieniu Uniwersytet Przyrodniczy w Poznaniu, 56-64.

33. Pszczółkowski P., Sawicka B. 2018. The effect of application of biopreparations and fungicides on the yield and selected parameters of seed value of seed potatoes. Acta Agrophysica, 25 (2), 239-255.

34. Puła J., Skowera B. 2004. Quality properties variability of potato tubers of Mila variety cultivated on light soil depending upon weather conditions [in Polish]. Acta Agrophys. 3 (2), 359-366.

35. Resolution of the General Meeting of the United Nations Organization A/RES/70/1 from 25 September 2015. We are changing our world: Agenda for the sustainable development 2030.

36. Rymuza, K., Zarzecka, K., Gugała, M. 2013. Usefulness of multidimensional comparative analysis for tuber quality assessment of potatoes. Fragmenta Agronomica, 30 (2), 134-142.
37. Sawicka B., Noaema A.H., Kiełtyka-Dadasiewicz A., Barbaś P. 2016. Nutritional value of potato tubers in conditions of using growth bioregulators [in Polish]. [In]: Bio products - obtaining, properties and application in foodstuff production. Edit. G. Lewandowicz, J. Le Thanh-Blicharz. Wydział Nauk o Żywności i Żywieniu Uniwersytet Przyrodniczy w Poznaniu, 65-73.

38. Scherr S.J., McNeely J.A. 2008. Biodiversity conservation and agricultural sustainability: towards a new paradigm of ,ecoagriculture” landscapes. Philos. T. Roy. Soc. B 363 (1491), 477-494.

39. Trawczyński C. 2016. The influence of cultivars and weather conditions of vegetation period on the content of some nutritional and anti-nutritional components in potato tubers [in Polish]. Acta Agrophysica, 23 (1), 119-128.

40. Van Oosten M.J., Pepe O., De Pascale S., Silletti S., Maggio A. 2017. The role of biostimulants and bioeffectors as alleviators of abiotic stress in crop plants. Chemical and Biological Technologies in Agriculture, 4 (5), 2-12.

41. Wichrowska D., Wojdyła T., Rogozińska I. 2009. Concentrations of some macroelements in potato tubers stored at $4^{\circ} \mathrm{C}$ and $8^{\circ} \mathrm{C}$. Journal of Elementology, 14(2), 373-38.

42. Wierzbicka A., Trawczyński C. 2011. Impact of irrigation and soil micro-organisms on the content of macro and micro elements in ecological potato tubers [in Polish]. Fragmenta Agronomica, 28 (4), 139-148.

43. Wierzbicka A., Trawczyński C. 2012. Factors affecting the protein content and protein yield in potato tubers [in Polish]. Biul. IHAR, 266, 181-190.

44. Wierzbowska J., Cwalina-Ambroziak B., GłosekSobieraj M., Sienkiewicz S. 2015. Effect of biostimulators on yield and selected chemical properties of potato tubers. Journal of Elementology, 20 (3), 757-768.

45. Zarzecka K., Gugała M. 2006. Content of total and major protein in potato tubers depending on the methods of land management and weeding [in Polish]. Acta Scientarum Polonorum Agricultura, 5 (2), 107-115.

46. Zarzecka K., Gugała M. 2012. Utilization of soil fertilizer UGmax in potato cultivation [in Polish]. Roczniki Naukowe SERiA XIV, (5), 215-218.

47. Zebarth B.J., Tai G., Tarn R., de Jong H., Milbum P.H. 2004. Nitrogen use efficiency characteristics of commercial potato cultivars. Canadian Journal of Plant Science, 84, 589-598.

48. Zimnoch-Guzowska E., Flis B. 2006. Genetic basis of quality features of potato [in Polish]. Zeszyty Problemowe Postępów Nauk Rolniczych, 511, 23-26. 